\title{
Green Chemistry: New Synthesis of Substituted Chromenes and Benzochromenes via Three-Component Reaction Utilizing Rochelle Salt as Novel Green Catalyst
}

\author{
Awatef Mohamed El-Maghraby \\ Department of Chemistry, Faculty of Science, South Valley University, Qena 83523, Egypt \\ Correspondence should be addressed to Awatef Mohamed El-Maghraby; awatef_elmaghraby@yahoo.com
}

Received 31 October 2013; Accepted 14 December 2013; Published 30 January 2014

Academic Editor: Ramadan A. Mekheimer

Copyright (C) 2014 Awatef Mohamed El-Maghraby. This is an open access article distributed under the Creative Commons Attribution License, which permits unrestricted use, distribution, and reproduction in any medium, provided the original work is properly cited.

\begin{abstract}
Substituted 2-amino-4-aryl-7-hydroxy- $4 H$-chromene-3-carbonitriles (6), 2-amino-4-aryl-4H-benzo[ $h]$ chromene-3-carbonitriles (7), and 3-amino-1-aryl-1H-benzo[f]chromenes-2-carbonitriles (8) were prepared, in good yields, via one-pot three-component reactions of aromatic aldehydes (1), malononitrile (2), and resorcinol (3) or $\alpha$-naphthol (4) or $\beta$-naphthol (5) in refluxing ethanol or water in the presence of Rochelle salt as novel green heterogeneous and reusable catalyst.
\end{abstract}

\section{Introduction}

Aminochromenes represent an important class of organic compounds being the main components of many naturally occurring products. In addition, they are valuable precursors used for the synthesis of cosmetics, pigments [1], and potentially biodegradable agrochemicals [2]. Furthermore, fused chromenes are important constituents of pharmacologically active compounds, as these systems have displayed a broad spectrum of biological activities such as antimicrobial [3, 4], mutagenicity [5], antiviral [6], antiproliferative [7], sex pheromonal [8], antitumor [9], central nervous system (CNS) activities [10], and inhibitors of influenza virus sialidases $[11,12]$. One-pot multicomponent reactions have received considerable attention in synthetic chemistry as they can produce target products from readily available starting materials in one reaction step without isolating the intermediates thus reducing reaction times, labor cost, and waste production [13]. In addition, water has emerged as a versatile solvent for organic reactions in the last two decades since it is readily available, inexpensive, environmentally benign, neutral, and a natural solvent $[14,15]$. For these reasons, water has been used for MCRs as well $[16,17]$. MCRs in water are of outstanding value in organic synthesis and green chemistry $[16,17]$. Aminochromenes have been prepared by heating a mixture of malononitrile, aldehyde, and activated phenol or naphthols in refluxing DMF or acetonitrile in the presence of hazardous organic bases such as piperidine and triethylamine $[18,19]$. Although different synthetic methods to prepare these heterocyclic systems have been reviewed [20-36], to the best of our knowledge, the use of clean solvents in combination with heterogeneous and reusable catalysts to synthesize these systems has not been largely reported [13, 25]. In continuation of our work concerning the synthesis and biological evaluation of new heterocycles [37-40] and aiming to explore the efficiency of Rochelle salt (R. S.) as a novel green heterogeneous and reusable catalyst in the onepot reactions in the organic syntheses, we report herein our results on the utility of Rochelle salt (R. S.) as a green catalyst in the three-component condensations between aromatic aldehydes, active methylene reagents, and activated phenols.

\section{Result and Discussion}

Our synthesis began with the reaction of a mixture of aromatic aldehydes $\mathbf{1 a}-\mathbf{h}$, malononitrile (2), and resorcinol (3) in refluxing ethanol containing a catalytic amount of Rochelle salt to give 2-amino-4-aryl-7-hydroxy- $4 \mathrm{H}$ chromene-3-carbonitriles 6a-h (Scheme 1), (Table 1). 


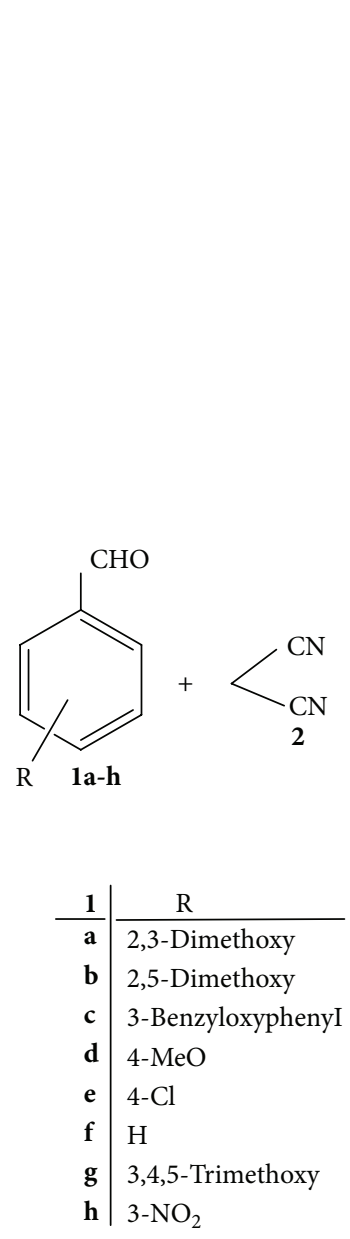

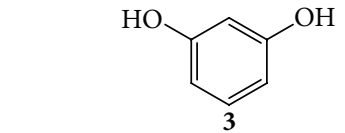
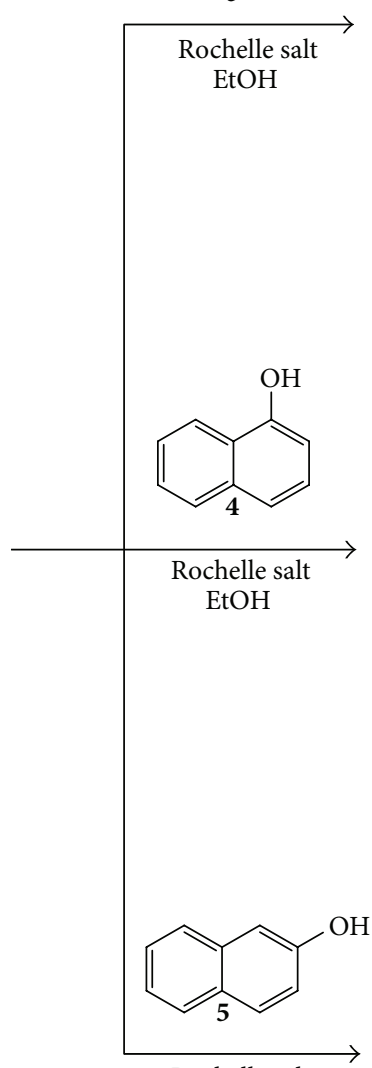

Rochelle salt $\mathrm{EtOH}$<smiles>[R]c1ccc(C2C(C#N)=C(N)Oc3cc(O)ccc32)cc1</smiles>

6a, $\mathrm{R}=2,3$-dimethoxy; $\mathbf{b}, \mathrm{R}=2,5$-dimethoxy;

c, $\mathrm{R}=3$-benzyloxyphenyl; d, $\mathrm{R}=4-\mathrm{MeO}$;

e, $\mathrm{R}=4$-Cl; f, $\mathrm{R}=\mathrm{H} ; \mathbf{g}, \mathrm{R}=3,4,5$-trimethoxy;

h, $3-\mathrm{NO}_{2}$<smiles>[R]c1ccccc1C1C(C#N)=C(N)Oc2c1ccc1ccccc21</smiles>

7a, $R=2,3$-dimethoxy; $\mathbf{b}, \mathrm{R}=2,5$-dimethoxy;

c, $\mathrm{R}=3,4,5$-trimethoxy; d, $\mathrm{R}=4$-Cl;

e, $\mathrm{R}=3-\mathrm{NO}_{2} ; \mathbf{f}, \mathrm{R}=\mathrm{H} ; \mathbf{g}, \mathrm{R}=4-\mathrm{MeO}$;<smiles>[R]CN1C(N)=C(C#N)C(c2ccccc2)c2c1ccc1ccccc21</smiles>

8a, $\mathrm{R}=2,3$-dimethoxy; $\mathbf{b}, \mathrm{R}=$ 2,4-dimethoxy;

c, $\mathrm{R}=3,4,5$-dimethoxy; $\mathbf{d}, \mathrm{R}=3,4,5$-trimethoxy;

e, $\mathrm{R}=3-\mathrm{NO}_{2}, \mathbf{f}, \mathrm{R}=4-\mathrm{MeO}, \mathbf{g}, \mathrm{R}=\mathrm{H} ; \mathbf{h}, \mathrm{R}=4-\mathrm{Cl}$

Scheme 1: Synthesis of compounds 6-8.

The structures of the isolated products $\mathbf{6 a}-\mathbf{h}$ were confirmed on the basis of their elemental analyses and spectral data. The IR spectrum of the reaction products showed the presence of both $\mathrm{OH}$ and $\mathrm{NH}_{2}$ functions at $3496-3320 \mathrm{~cm}^{-1}$ and a cyano at $\sim 2200 \mathrm{~cm}^{-1}$. The ${ }^{1} \mathrm{H}$ NMR spectra displayed the presence of two singlets at $\delta=6.37-6.87$ and 9.39$9.61 \mathrm{ppm}$ attributable to the amino $\left(\mathrm{NH}_{2}\right)$ and $\mathrm{OH}$ groups, respectively. Furthermore, the ${ }^{1} \mathrm{H}$ NMR gave strong evidence for the formation of compounds $\mathbf{6 a}-\mathbf{h}$. The data confirmed the presence of the $\mathrm{H}-4$ proton at $\delta=4.57-4.92 \mathrm{ppm}$, in addition to the signals of aromatic protons and other groups (see Table 3). Moreover, their structures were supported by both correct mass spectra and analytical data, which were compatible with the proposed structures for compounds $\mathbf{6 a}-\mathbf{h}$.

Since our interest is in developing a synthetic approach with a view to synthesize new derivatives of the interesting aminochromenes, $\alpha$-naphthol (4) and $\beta$-naphthol (5), good precursors for this purpose, were thus investigated. Reacting a mixture of aromatic aldehydes $\mathbf{l a}-\mathbf{h}$, malononitrile (2) and $\alpha$-naphthol (4) or $\beta$-naphthol (5), under the same reaction conditions, gave the 2-amino-4-aryl- $4 \mathrm{H}$ benzo $[h]$ chromene-3-carbonitriles 7a-g and 3-amino-1-aryl$1 H$-benzo $[f]$-chromenes-2-carbonitriles $\mathbf{8 a}-\mathbf{h}$, respectively, in good yields. The structures of these products (7) and (8) were established by correct elemental analyses and spectral data, which were compatible with the assigned structures. (cf. Tables 2 and 3 ).

On the other hand, heating a mixture of aromatic aldehydes (1a-h), malononitrile (2), and resorcinol (3) in boiling water containing a catalytic amount of Rochelle salt gave 2amino-4-aryl-7-hydroxy- $4 H$-chromene-3-carbonitriles 6a$\mathbf{h}$, in excellent yields. In contrast, neither $\alpha$-naphthol nor 
TABLE 1: Yields and melting points of the synthesized compounds 6-8.

\begin{tabular}{|c|c|c|c|c|c|}
\hline Compound & $\mathrm{R}$ & Yield \% & Observed m.p. & Reported m.p. & References \\
\hline $6 a$ & 2,3-Dimethoxy & 85 & 250 & - & - \\
\hline $6 b$ & 2,5-Dimethoxy & 85 & 170 & - & - \\
\hline $6 c$ & 3-Benzyloxyphenyl & 86 & 230 & - & - \\
\hline $6 d$ & 4-MeO & 86 & $112-114$ & $111-112$ & {$[30,32]$} \\
\hline $6 e$ & $4-\mathrm{Cl}$ & 90 & 184 & 164 & {$[30]$} \\
\hline $6 f$ & $\mathrm{H}$ & 80 & 228 & 231 & {$[32]$} \\
\hline $6 g$ & 3,4,5-Trimethoxy & 85 & 210 & 205 & {$[34]$} \\
\hline $6 \mathrm{~h}$ & $3-\mathrm{NO}_{2}$ & 84 & 170 & $169-170$ & {$[32]$} \\
\hline $7 \mathbf{a}$ & 2,3-Dimethoxy & 85 & 260 & - & - \\
\hline $7 \mathbf{b}$ & 2,5-Dimethoxy & 75 & 240 & - & - \\
\hline $7 c$ & 3,4,5-Trimethoxy & 80 & 190 & 189 & {$[35]$} \\
\hline $7 d$ & $4-\mathrm{Cl}$ & 90 & 235 & 232 & {$[20]$} \\
\hline $7 e$ & $3-\mathrm{NO}_{2}$ & 82 & 210 & 212 & {$[20]$} \\
\hline $7 f$ & $\mathrm{H}$ & 90 & 205 & 205 & {$[20]$} \\
\hline $7 \mathrm{~g}$ & $4-\mathrm{MeO}$ & 84 & 204 & 205 & {$[35]$} \\
\hline $\mathbf{8 a}$ & 2,3-Dimethoxy & 80 & 240 & - & - \\
\hline $8 b$ & 2,4-Dimethoxy & 80 & 205 & - & - \\
\hline $8 c$ & 2,5-Dimethoxy & 75 & 206 & - & - \\
\hline 8d & 3,4,5-Trimethoxy & 85 & 209 & - & - \\
\hline $8 \mathrm{e}$ & $3-\mathrm{NO}_{2}$ & 81 & 195 & 190 & [29] \\
\hline $8 f$ & $4-\mathrm{MeO}$ & 92 & 260 & 255 & {$[26]$} \\
\hline $8 g$ & $\mathrm{H}$ & 90 & 280 & $278-280$ & {$[20]$} \\
\hline $8 \mathrm{~h}$ & $4-\mathrm{Cl}$ & 83 & 187 & 191 & [29] \\
\hline
\end{tabular}

TABLE 2: Elemental analyses of the newly synthesized compounds 6-8.

\begin{tabular}{|c|c|c|c|c|c|}
\hline \multirow{2}{*}{ Compound } & \multirow{2}{*}{ Mol. formula/M.Wt. } & \multicolumn{4}{|c|}{ Elemental analysis } \\
\hline & & & $\mathrm{C} \%$ & $\mathrm{H} \%$ & $\mathrm{~N} \%$ \\
\hline \multirow{2}{*}{$6 a$} & \multirow{2}{*}{$\begin{array}{c}\mathrm{C}_{18} \mathrm{H}_{16} \mathrm{~N}_{2} \mathrm{O}_{4} \\
(324.35)\end{array}$} & Calc. & 66.66 & 4.97 & 8.64 \\
\hline & & Found & 66.41 & 5.12 & 8.34 \\
\hline \multirow{2}{*}{$6 b$} & \multirow{2}{*}{$\begin{array}{c}\mathrm{C}_{18} \mathrm{H}_{16} \mathrm{~N}_{2} \mathrm{O}_{4} \\
(324.35)\end{array}$} & Calc. & 66.66 & 4.97 & 8.64 \\
\hline & & Found & 67.01 & 5.13 & 9.01 \\
\hline \multirow{2}{*}{$6 c$} & \multirow{2}{*}{$\begin{array}{c}\mathrm{C}_{23} \mathrm{H}_{18} \mathrm{~N}_{2} \mathrm{O}_{3} \\
(370.40)\end{array}$} & Calc. & 74.58 & 4.90 & 7.56 \\
\hline & & Found & 76.86 & 4.75 & 7.15 \\
\hline \multirow{2}{*}{$7 \mathbf{a}$} & \multirow{2}{*}{$\begin{array}{c}\mathrm{C}_{22} \mathrm{H}_{18} \mathrm{~N}_{2} \mathrm{O}_{3} \\
(358.39)\end{array}$} & Calc. & 73.73 & 5.06 & 7.82 \\
\hline & & Found & 74.11 & 5.20 & 8.07 \\
\hline \multirow{2}{*}{$7 \mathbf{b}$} & \multirow{2}{*}{$\begin{array}{c}\mathrm{C}_{22} \mathrm{H}_{18} \mathrm{~N}_{2} \mathrm{O}_{3} \\
(358.39)\end{array}$} & Calc. & 73.73 & 5.06 & 7.82 \\
\hline & & Found & 74.02 & 5.38 & 7.58 \\
\hline \multirow{2}{*}{$8 \mathbf{a}$} & \multirow{2}{*}{$\begin{array}{c}\mathrm{C}_{22} \mathrm{H}_{18} \mathrm{~N}_{2} \mathrm{O}_{3} \\
(358.39)\end{array}$} & Calc. & 73.73 & 5.06 & 7.82 \\
\hline & & Found & 74.11 & 5.74 & 8.21 \\
\hline \multirow{2}{*}{$8 b$} & \multirow{2}{*}{$\begin{array}{c}\mathrm{C}_{22} \mathrm{H}_{18} \mathrm{~N}_{2} \mathrm{O}_{3} \\
(358.39)\end{array}$} & Calc. & 73.73 & 5.06 & 7.82 \\
\hline & & Found & 73.63 & 4.83 & 8.19 \\
\hline \multirow{2}{*}{$8 c$} & \multirow{2}{*}{$\begin{array}{c}\mathrm{C}_{22} \mathrm{H}_{18} \mathrm{~N}_{2} \mathrm{O}_{3} \\
(358.39)\end{array}$} & Calc. & 73.73 & 5.06 & 7.82 \\
\hline & & Found & 73.52 & 5.24 & 7.63 \\
\hline \multirow{2}{*}{$8 d$} & \multirow{2}{*}{$\begin{array}{c}\mathrm{C}_{23} \mathrm{H}_{20} \mathrm{~N}_{2} \mathrm{O}_{4} \\
(388.42)\end{array}$} & Calc. & 71.12 & 5.19 & 7.21 \\
\hline & & Found & 71.34 & 5.40 & 7.50 \\
\hline
\end{tabular}

$\beta$-naphthol underwent the above one-pot three-component reactions in boiling water even upon heating for extended periods. When, a mixture of ethanol/water was used as a solvent in the previous reactions, the three phenols gave the desired products $\mathbf{6} \mathbf{a}-\mathbf{h}, \mathbf{7} \mathbf{a}-\mathbf{g}$, and $\mathbf{8 a}-\mathbf{h}$, in good yields. All known compounds were identical in all physical and spectroscopic aspects with the others which are reported in literatures. 
TABLE 3: Spectral data of the newly synthesized compounds 6-8.

\begin{tabular}{|c|c|c|c|}
\hline Compound & $\operatorname{IR}\left(\mathrm{cm}^{-1}\right)$ & MS & ${ }^{1} \mathrm{H}$ NMR $\left(\mathrm{DMSO}-d_{6}\right)(\delta \mathrm{ppm})$ \\
\hline $6 a$ & $3419-3327\left(\mathrm{OH}\right.$ and $\left.\mathrm{NH}_{2}\right), 2190(\mathrm{CN})$ & $324\left(\mathrm{M}^{+}\right)$ & $\begin{array}{l}3.65\left(\mathrm{~s}, 3 \mathrm{H}, \mathrm{OCH}_{3}\right), 3.70\left(\mathrm{~s}, 3 \mathrm{H}, \mathrm{OCH}_{3}\right), 4.89(\mathrm{~s}, 1 \mathrm{H}, \mathrm{H}-4), 6.75(\mathrm{~s}, 2 \mathrm{H}, \\
\left.\mathrm{NH}_{2}\right), 6.45-6.74(\mathrm{~m}, 6 \mathrm{H}, \mathrm{ArH}), 9.61(\text { br s, } 1 \mathrm{H}, \mathrm{OH}) .\end{array}$ \\
\hline $6 \mathbf{b}$ & $3430-3325\left(\mathrm{OH}\right.$ and $\left.\mathrm{NH}_{2}\right), 2210(\mathrm{CN})$ & $324\left(\mathrm{M}^{+}\right)$ & $\begin{array}{l}3.68\left(\mathrm{~s}, 3 \mathrm{H}, \mathrm{OCH}_{3}\right), 3.73\left(\mathrm{~s}, 3 \mathrm{H}, \mathrm{OCH}_{3}\right), 4.92(\mathrm{~s}, 1 \mathrm{H}, \mathrm{H}-4), 6.37(\mathrm{~s}, 2 \mathrm{H}, \\
\left.\mathrm{NH}_{2}\right), 6.53-6.75(\mathrm{~m}, 6 \mathrm{H}, \mathrm{ArH}), 9.51(\mathrm{br} \mathrm{s}, 1 \mathrm{H}, \mathrm{OH}) .\end{array}$ \\
\hline $6 c$ & $3430-3320\left(\mathrm{OH}\right.$ and $\left.\mathrm{NH}_{2}\right), 2215(\mathrm{CN})$ & $370\left(\mathrm{M}^{+}\right)$ & $\begin{array}{l}4.57(\mathrm{~s}, 1 \mathrm{H}, \mathrm{H}-4), 5.04\left(\mathrm{~s}, 2 \mathrm{H},-\mathrm{CH}_{2}-\right), 6.75-6.82(\mathrm{~m}, 5 \mathrm{H}, \mathrm{ArH}), 6.87 \\
\left(\mathrm{~s}, 2 \mathrm{H}, \mathrm{NH}_{2}\right), 7.22-7.37(\mathrm{~m}, 3 \mathrm{H}, \mathrm{ArH}), 7.40-7.44(\mathrm{~m}, 4 \mathrm{H}, \mathrm{ArH}), 9.39 \\
(\mathrm{br} \mathrm{s}, 1 \mathrm{H}, \mathrm{OH})\end{array}$ \\
\hline $7 a$ & $3387,3310\left(\mathrm{NH}_{2}\right), 2190(\mathrm{CN})$ & $358\left(\mathrm{M}^{+}\right)$ & $\begin{array}{l}3.64\left(\mathrm{~s}, 3 \mathrm{H}, \mathrm{OCH}_{3}\right), 3.79\left(\mathrm{~s}, 3 \mathrm{H}, \mathrm{OCH}_{3}\right), 5.14(\mathrm{~s}, 1 \mathrm{H}, \mathrm{H}-4), 6.69(\mathrm{~s}, 2 \mathrm{H} \text {, } \\
\left.\mathrm{NH}_{2}\right), 7.0-7.53(\mathrm{~m}, 9 \mathrm{H}, \mathrm{ArH}) .\end{array}$ \\
\hline $7 \mathbf{b}$ & $3387,3315\left(\mathrm{NH}_{2}\right), 2195(\mathrm{CN})$ & $358\left(\mathrm{M}^{+}\right)$ & $\begin{array}{l}3.71\left(\mathrm{~s}, 3 \mathrm{H}, \mathrm{OCH}_{3}\right), 3.80\left(\mathrm{~s}, 3 \mathrm{H}, \mathrm{OCH}_{3}\right), 4.54(\mathrm{~s}, 1 \mathrm{H}, \mathrm{H}-4), 6.72(\mathrm{~s}, 2 \mathrm{H} \text {, } \\
\left.\mathrm{NH}_{2}\right), 7.10-7.53(\mathrm{~m}, 9 \mathrm{H}, \mathrm{ArH}) .\end{array}$ \\
\hline $8 \mathbf{a}$ & $3460,3340\left(\mathrm{NH}_{2}\right), 2200(\mathrm{CN})$ & $358\left(\mathrm{M}^{+}\right)$ & $\begin{array}{l}3.85\left(\mathrm{~s}, 3 \mathrm{H}, \mathrm{OCH}_{3}\right), 4.01\left(\mathrm{~s}, 3 \mathrm{H}, \mathrm{OCH}_{3}\right), 4.62(\mathrm{~s}, 1 \mathrm{H}, \mathrm{H}-4), 6.66(\mathrm{~s}, 2 \mathrm{H}, \\
\left.\mathrm{NH}_{2}\right), 7.21-7.45(\mathrm{~m}, 9 \mathrm{H}, \mathrm{ArH}) .\end{array}$ \\
\hline $8 \mathbf{b}$ & $3445,3300\left(\mathrm{NH}_{2}\right), 2201(\mathrm{CN})$ & $358\left(\mathrm{M}^{+}\right)$ & $\begin{array}{l}3.82\left(\mathrm{~s}, 3 \mathrm{H}, \mathrm{OCH}_{3}\right), 3.90\left(\mathrm{~s}, 3 \mathrm{H}, \mathrm{OCH}_{3}\right), 4.54(\mathrm{~s}, 1 \mathrm{H}, \mathrm{H}-4), 6.72(\mathrm{~s}, 2 \mathrm{H}, \\
\left.\mathrm{NH}_{2}\right), 7.28-7.53(\mathrm{~m}, 9 \mathrm{H}, \mathrm{ArH}) .\end{array}$ \\
\hline $8 \mathrm{c}$ & $3450,3320\left(\mathrm{NH}_{2}\right), 2187(\mathrm{CN})$ & $358\left(\mathrm{M}^{+}\right)$ & $\begin{array}{l}3.73\left(\mathrm{~s}, 3 \mathrm{H}, \mathrm{OCH}_{3}\right), 3.82\left(\mathrm{~s}, 3 \mathrm{H}, \mathrm{OCH}_{3}\right), 4.55(\mathrm{~s}, 1 \mathrm{H}, \mathrm{H}-4), 6.69(\mathrm{~s}, 2 \mathrm{H}, \\
\left.\mathrm{NH}_{2}\right), 7.29-7.52(\mathrm{~m}, 9 \mathrm{H}, \mathrm{ArH}) .\end{array}$ \\
\hline $8 d$ & $3465,3310\left(\mathrm{NH}_{2}\right), 2191(\mathrm{CN})$ & $388\left(\mathrm{M}^{+}\right)$ & $\begin{array}{l}3.70\left(\mathrm{~s}, 3 \mathrm{H}, \mathrm{OCH}_{3}\right), 3.81\left(\mathrm{~s}, 3 \mathrm{H}, \mathrm{OCH}_{3}\right), 3.89\left(\mathrm{~s}, 3 \mathrm{H}, \mathrm{OCH}_{3}\right), 4.50(\mathrm{~s}, \\
1 \mathrm{H}, \mathrm{H}-4), 6.64\left(\mathrm{~s}, 2 \mathrm{H}, \mathrm{NH}_{2}\right), 7.11-7.78(\mathrm{~m}, 8 \mathrm{H}, \mathrm{ArH}) .\end{array}$ \\
\hline
\end{tabular}

\section{Conclusions}

We have discovered a green and efficient synthetic route to some new chromenes, namely, 2-amino chromenes, benzo $[h]$ chromenes and benzo $[f]$ chromenes, of expected biological interest, by utilizing Rochelle salt as novel green catalyst. To the best of our knowledge, this is the first time for utilizing Rochelle salt, as an efficient, green, and cheap catalyst in the one-pot three-component reactions.

\section{Experimental}

4.1. General. All melting points were measured on a Gallenkamp apparatus and are uncorrected. IR spectra were recorded with a Shimadzu FT-IR 8101 PC spectrophotometer in $\mathrm{KBr}$ disks. ${ }^{1} \mathrm{H}$ NMR spectra were recorded with Bruker AM 300 spectrometer at $300 \mathrm{MHz}$ with $\mathrm{DMSO}-d_{6}$ and $\mathrm{CDCl}_{3}$ as solvents and TMS as an internal standards; chemical shifts $(\delta)$ are reported in ppm. Mass spectra were measured on a GCMS-QP1000 EX (EI, 70 eV) mass spectrometer. Analytical thin-layer chromatography (TLC) was performed on Merck silica gel 60 plates, $0.25 \mathrm{~mm}$ thick with F-254 indicator. Visualization was accomplished by UV light. Solvents for chromatography were reagent grad and used as received. Microanalyses were performed by the microanalytical Data Unit at Cairo University.

General Procedure for the Synthesis of 2-Amino-4-aryl-7hydroxy-4H-chromene-3-carbonitriles 6a-h.

Method (A). To a mixture of equimolar amounts of aromatic aldehydes $\mathbf{1 a}-\mathbf{h}$, malonontirile (2), and resorcinol (3) $(5 \mathrm{mmol})$ in ethanol or ethanol/water mixture $(1: 1)(10 \mathrm{~mL})$, Rochelle salt $(0.30 \mathrm{~g})$ was added. Then, the reaction mixture was heated at reflux temperature for $2-4 \mathrm{~h}$. After cooling to room temperature, the resulting solid products were collected by filtration, dried, and recrystallized from $\mathrm{EtOH}$ to give chromenes $\mathbf{6 a}-\mathbf{h}$.

Method (B). To a mixture of equimolar amounts of aromatic aldehydes $\mathbf{l a}-\mathbf{h}$, malononirile (2), and resorcinol (3) $(5 \mathrm{mmol})$ in $\mathrm{H}_{2} \mathrm{O}(10 \mathrm{~mL})$, Rochelle salt $(0.3 \mathrm{~g})$ was added. Then, the reaction mixture was worked up as described above to give chromenes $\mathbf{6 a - h}$.

General Procedure for the Synthesis of 2-Amino-4-aryl-4Hbenzo[h]chromene-3-carbonitriles $7 a-g$ and 3-Amino-1-aryl$1 H$-benzo[f]chromenes-2-carbonitriles $8 a-h$. To a mixture of equimolar amounts of aromatic aldehydes $\mathbf{1 a}-\mathbf{h}$, malononirile (2) and 1-naphthol (4) (or 2-naphthol (5)) (5 mmol) in ethanol or ethanol/water mixture $(1: 1)(10 \mathrm{~mL})$, Rochelle salt $(0.3 \mathrm{~g})$ was added. The reaction mixture was refluxed for $4-$ $8 \mathrm{~h}$. After cooling to room temperature, the resulting solid products were collected by filtration, dried, and recrystallized from $\mathrm{EtOH}$ to give the products $7 \mathbf{a}-\mathbf{g}$ and $\mathbf{8 a}-\mathbf{h}$, respectively.

\section{Conflict of Interests}

The author declares that there is no conflict of interests regarding the publication of this paper.

\section{References}

[1] G. P. Ellis, "Chromenes, chromanones, and chromones," in The Chemistry of Heterocyclic Compounds Chromenes, A. Weissberger and E. C. Taylor, Eds., chapter 2, pp. 11-139, John Wiley, New York, NY, USA, 1977.

[2] E. A. A. Hafez, M. H. Elnagdi, A. G. A. Elagamey, and F. M. A. A. El-Taweel, "Nitriles in heterocyclic synthesis: novel synthesis of benzo[c]-coumarin and of benzo[c]pyrano[3,2-c] quinoline derivatives," Heterocycles, vol. 26, no. 4, pp. 903-907, 1987. 
[3] M. M. Khafagy, A. H. F. A. El-Wahab, F. A. Eid, and A. M. ElAgrody, "Synthesis of halogen derivatives of benzo[ $h]$ chromene and benzo $[a]$ anthracene with promising antimicrobial activities," Farmaco, vol. 57, no. 9, pp. 715-722, 2002.

[4] A. H. Bedair, H. A. Emam, N. A. El-Hady, K. A. R. Ahmed, and A. M. El-Agrody, "Synthesis and antimicrobial activities of novel naphtho[2,1-b]pyran, pyrano[2,3- $d]$ pyrimidine and pyrano[3,2-e][1,2,4] triazolo[2,3-c]-pyrimidine derivatives," Farmaco, vol. 56, no. 12, pp. 965-973, 2001.

[5] K. Hiramoto, A. Nasuhara, K. Michikoshi, T. Kato, and K. Kikugawa, "DNA strand-breaking activity and mutagenicity of 2,3dihydro-3,5-dihydroxy-6-methyl-4H-pyran-4-one (DDMP), a Maillard reaction product of glucose and glycine," Mutation Research, vol. 395, no. 1, pp. 47-56, 1997.

[6] A. Martínez-Grau and J. L. Marco, "Friedlander reaction on 2-amino-3-cyano-4H-pyrans: synthesis of derivates of $4 \mathrm{H}$ pyran[2,3-b]quinoline, new tacrine analogues," Bioorganic and Medicinal Chemistry Letters, vol. 7, no. 24, pp. 3165-3170, 1997.

[7] C. P. Dell and C. W. Smith, "Antiproliferative derivatives of 4Hnaphtho[1,2-b]pyran and process for their preparation," European Patent Applications EP 53794921 Aprl. 993; Chemical Abstracts 119, 139102d, 1993.

[8] G. Bianchi and A. Tava, "Synthesis of (2R)(+)-2,3-dihydro-2,6dimethyl- $4 H$-pyran-4-one, a homologue of pheromones of a species in the hepialidae family," Agricultural and Biological Chemistry, vol. 51, pp. 2001-2002, 1987.

[9] S. J. Mohr, M. A. Chirigos, F. S. Fuhrman, and J. W. Pryor, "Pyran copolymer as an effective adjuvant to chemotherapy against a murine leukemia and solid tumor," Cancer Research, vol. 35, no. 12, pp. 3750-3754, 1975.

[10] F. Eiden and F. Denk, "Synthesis and CNS-activity of pyran derivatives: 6,8-dioxabicyclo[3,2,1]octanes," Archiv der Pharmazie, vol. 324, no. 6, pp. 353-354, 1991.

[11] P. W. Smith, S. L. Sollis, P. D. Howes et al., "Dihydropyrancarboxamides related to zanamivir: a new series of inhibitors of influenza virus sialidases. 1. Discovery, synthesis, biological activity, and structure-activity relationships of 4-guanidinoand 4-amino-4H-pyran-6-carboxamides," Journal of Medicinal Chemistry, vol. 41, no. 6, pp. 787-797, 1998.

[12] R. N. Taylor, A. Cleasby, O. Singh et al., "Dihydropyranocarboxamides related to zanamivir: a new series of inhibitors of influenza virus sialidases," Journal of Medicinal Chemistry, vol. 41, no. 6, pp. 798-807, 1998.

[13] R. Maggi, R. Ballini, G. Sartori, and R. Sartorio, "Basic alumina catalysed synthesis of substituted 2-amino-2-chromenes via three-component reaction," Tetrahedron Letters, vol. 45, no. 11, pp. 2297-2299, 2004.

[14] C. J. Li and T. H. Chan, Organic Reactions in AqueousMedia, Wiley, New York, NY, USA, 1997.

[15] P. A. Grieco, Organic Synthesis in Water, Blackie Academic and Professional, 1998.

[16] K. Kandhasamy and V. Gnanasambandam, "Multi-component reactions in water," Current Organic Chemistry, vol. 13, pp. 1820$11841,2009$.

[17] C. K. Z. Andrade and L. M. Alves, "Environmentally benign solvents in organic synthesis," Current Topics in Medicinal Chemistry, vol. 9, pp. 195-218, 2005.

[18] A. G. A. Elagamay and F. M. A. A. El-Taweel, "Nitriles in heterocyclic synthesis: synthesis of condensed pyrans.," Indian Journal of Chemistry B, vol. 29, pp. 885-886, 1990.
[19] M. M. Heravi, B. Baghernejad, and H. A. Oskooie, "A novel and efficient catalyst to one-pot synthesis of 2-amino- $4 \mathrm{H}$ chromenes by methanesulfonic acid," Journal of the Chinese Chemical Society, vol. 55, no. 3, pp. 659-662, 2008.

[20] M. M. Heravi, K. Bakhtiari, V. Zadsirjan, F. F. Bamoharram, and O. M. Heravi, "Aqua mediated synthesis of substituted 2-amino$4 H$-chromenes catalyzed by green and reusable Preyssler heteropolyacid," Bioorganic and Medicinal Chemistry Letters, vol. 17, no. 15, pp. 4262-4265, 2007.

[21] R. Ballini, G. Bosica, M. L. Conforti et al., “Three-component process for the synthesis of 2-amino-2-chromenes in aqueous media," Tetrahedron, vol. 57, no. 7, pp. 1395-1398, 2001.

[22] L. Chen, X.-J. Huang, Y.-Q. Li, M.-Y. Zhou, and W.-J. Zheng, "A one-pot multicomponent reaction for the synthesis of 2-amino2-chromenes promoted by $N, N$-dimethylamino-functionalized basic ionic liquid catalysis under solvent-free condition," Monatshefte fur Chemie, vol. 140, no. 1, pp. 45-47, 2009.

[23] J. Albadi, A. Mansournezhad, and M. Darvishi-Paduk, "Poly(4vinylpyridine): as a green, efficient and commercial available basic catalyst for the synthesis of chromene derivatives," Chinese Chemical Letters, vol. 24, pp. 208-210, 2013.

[24] M. Kidwai, S. Saxena, M. K. R. Khan, and S. S. Thukral, "Aqua mediated synthesis of substituted 2-amino- $4 H$-chromenes and in vitro study as antibacterial agents," Bioorganic and Medicinal Chemistry Letters, vol. 15, no. 19, pp. 4295-4298, 2005.

[25] H. M. Al-Matar, K. D. Khalil, H. Meier, H. Kolshorn, and M. H. Elnagdi, "Chitosan as heterogeneous catalyst in Michael additions: the reaction of cinnamonitriles with active methylene moieties and phenols," Arkivoc, vol. 2008, no. 16, pp. 288-301, 2008.

[26] B. S. Kumar, N. Srinivasulu, R. H. Udupi et al., "Efficient synthesis of benzo $[g]$ - and benzo $[h]$ chromene derivatives by one-pot three-component condensation of aromatic aldehydes with active methylene compounds and naphthols," Russian Journal of Organic Chemistry, vol. 42, no. 12, pp. 1813-1815, 2006.

[27] S. R. Kolla and Y. R. Lee, " $\mathrm{Ca}(\mathrm{OH})_{2}$-mediated efficient synthesis of 2-amino-5-hydroxy- $4 \mathrm{H}$ - chromene derivatives with various substituents," Tetrahedron, vol. 67, no. 43, pp. 8271-8275, 2011.

[28] D. Kumar, V. B. Reddy, B. G. Mishra, R. K. Rana, M. N. Nadagoudac, and R. S. Varma, "Nanosized magnesium oxide as catalyst for the rapid and green synthesis of substituted 2-amino-2-chromenes.," Tetrahedron, vol. 63, pp. 3093-3097, 2007.

[29] H. Sheibani, K. Saidi, M. Abbasnejad, A. Derakhshani, and I. Mohammadzadeh, "A convenient one-pot synthesis and anxietic activity of 3-cyano-2 $(1 H)$-iminopyridines and halogen derivatives of benzo[h]chromenes," Arabian Journal of Chemistry, 2011.

[30] S. Makarem, A. A. Mohammadi, and A. R. Fakhari, "A multi-component electro-organic synthesis of 2-amino- $4 \mathrm{H}$ chromenes," Tetrahedron Letters, vol. 49, no. 50, pp. 7194-7196, 2008.

[31] R. A. Mekheimer and K. U. Sadek, "Microwave-assisted reactions: three-component process for the synthesis of 2-amino2-chromenes under microwave heating," Chinese Chemical Letters, vol. 20, no. 3, pp. 271-274, 2009.

[32] S. Khaksar, A. Rouhollahpour, and S. M. Talesh, "A facile and efficient synthesis of 2-amino-3-cyano- $4 \mathrm{H}$-chromenes and tetrahydrobenzo $[b]$ pyrans using 2,2,2-trifluoroethanol as a metal-free and reusable medium," Journal of Fluorine Chemistry, vol. 141, pp. 11-15, 2012. 
[33] M. P. Surpur, S. Kshirsagar, and S. D. Samant, "Exploitation of the catalytic efficacy of $\mathrm{Mg} / \mathrm{Al}$ hydrotalcite for the rapid synthesis of 2-aminochromene derivatives via a multicomponent strategy in the presence of microwaves," Tetrahedron Letters, vol. 50, no. 6, pp. 719-722, 2009.

[34] D. S. Raghuvanshi and K. N. Singh, "An expeditious synthesis of novel pyranopyridine derivatives involving chromenes under controlled microwave irradiatio," Arkivoc, pp. 305-317, 2010.

[35] J. M. Khurana, B. Nand, and P. Saluja, "DBU: a highly efficient catalyst for one-pot synthesis of substituted 3, 4dihydropyrano[3,2-c]chromenes, dihydropyrano[4,3- $b]$ pyranes, 2-amino- $4 H$-benzo[ $h]$ chromenes and 2 -amino- $4 H$ benzo $[g]$ chromenes in aqueous medium," Tetrahedron, vol. 66, no. 30, pp. 5637-5641, 2010.

[36] A. V. Borhade, B. K. Uphade, and D. R. Tope, "PbO as an efficient and reusable catalyst for one-pot synthesis of tetrahydro benzo pyrans and benzylidene malonitriles," Journal of Chemical Sciences, vol. 125, pp. 583-589, 2013.

[37] A. A. Harb, A. M. El-Maghraby, and S. A. Metwally, "Nitriles in heterocyclic synthesis: a New synthesis of some $4 \mathrm{H}$ naphthopyrans, $2 \mathrm{H}$-benzothiopyrans and their fused derivatives," Collection of Czechoslovak Chemical Communications, vol. 57, pp. 1570-1574, 1992.

[38] A. M. El-Maghraby, "Synthesis of some new pyrazolo[4,3b]pyridine-3-one and dihydro-pyrazolo[4,3-c][1,2]oxazine derivatives," Egyptian Journal of Chemistry, vol. 51, pp. 373-388, 2008.

[39] O. S. Zaky, M. S. Moustafa, M. A. Selim, A. M. El- Maghraby, and M. H. Elnagdi, "Scope and limitations of a novel synthesis of 3-arylazonicotinates," Molecules, vol. 17, pp. 5924-5934, 2012.

[40] A. M. Elmaghraby, I. A. Mousa, A. A. Harb, and M. Y. Mahgoub, "Three component reaction: an efficient synthesis and reactions of 3,4-dihydropyrimidin-2(1H)-ones and thiones using new natural catalyst," ISRN Organic Chemistry, vol. 2013, Article ID 706437, 13 pages, 2013. 

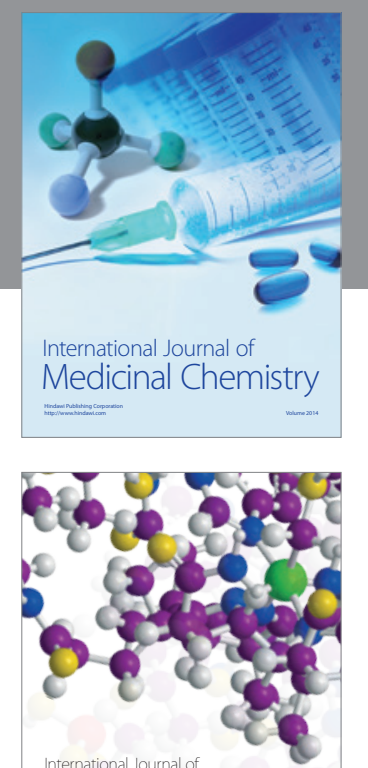

\section{Carbohydrate} Chemistry

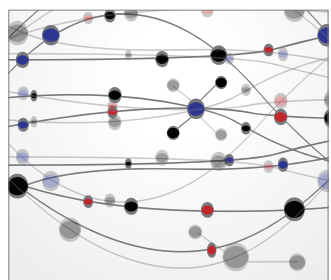

The Scientific World Journal
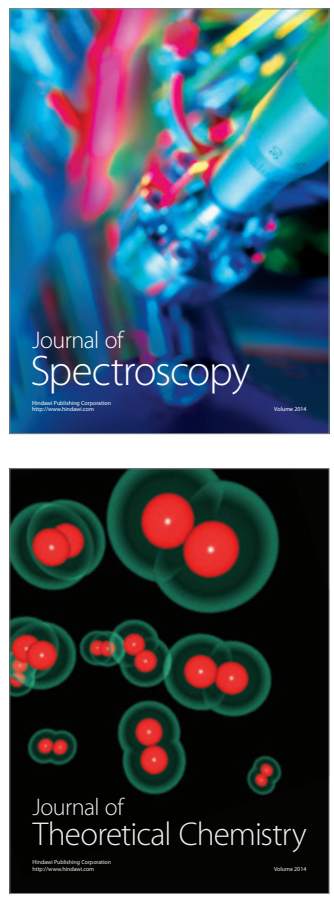
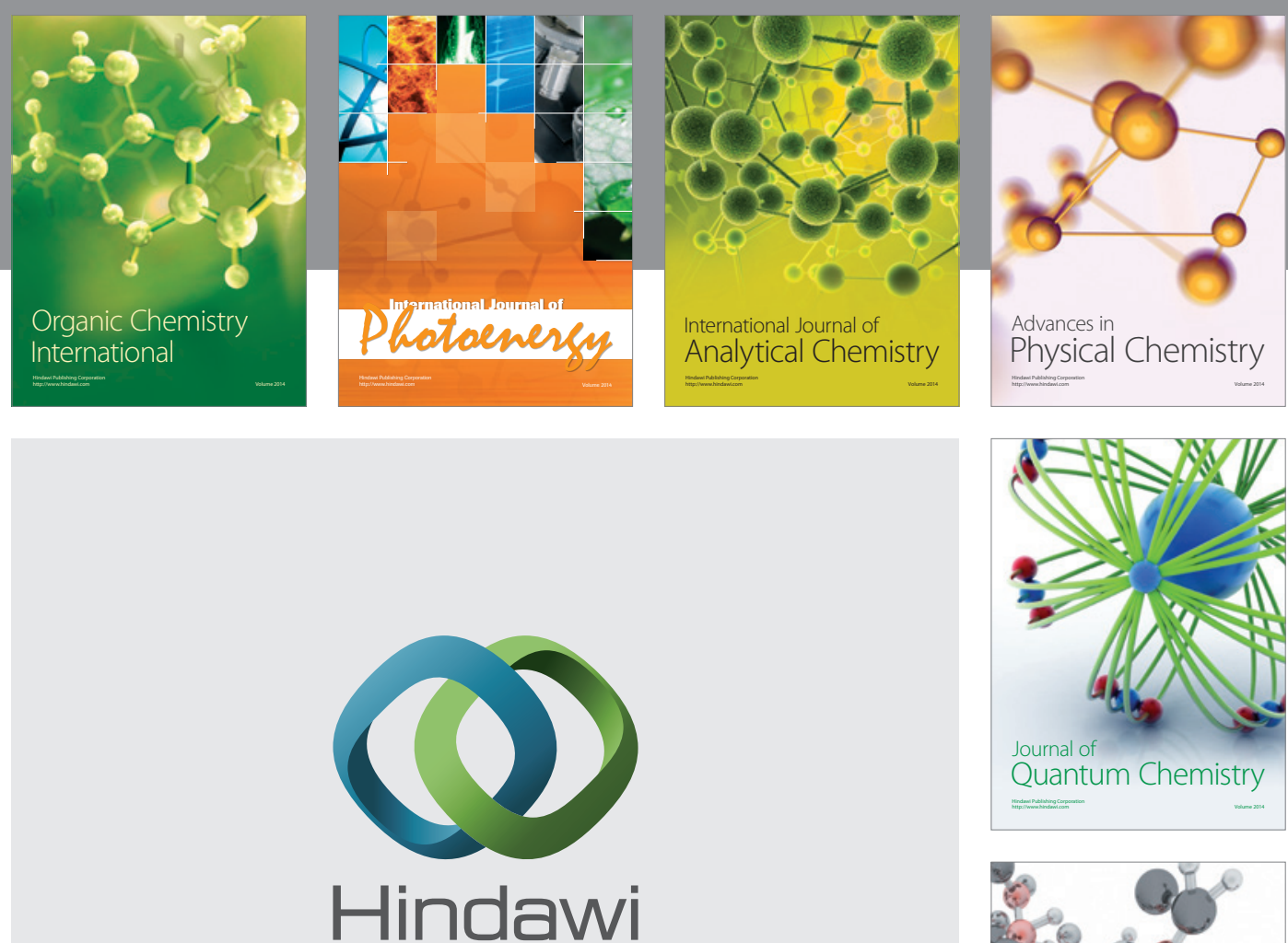

Submit your manuscripts at

http://www.hindawi.com

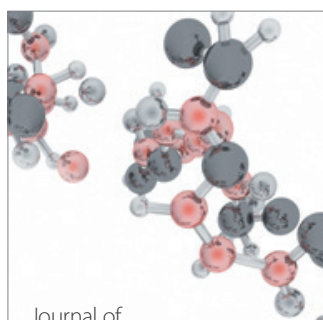

Analytical Methods

in Chemistry

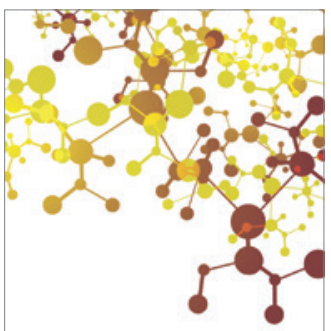

Journal of

Applied Chemistry

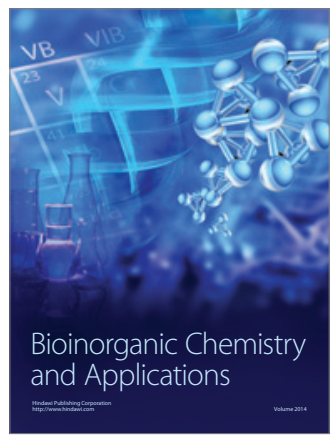

Inorganic Chemistry
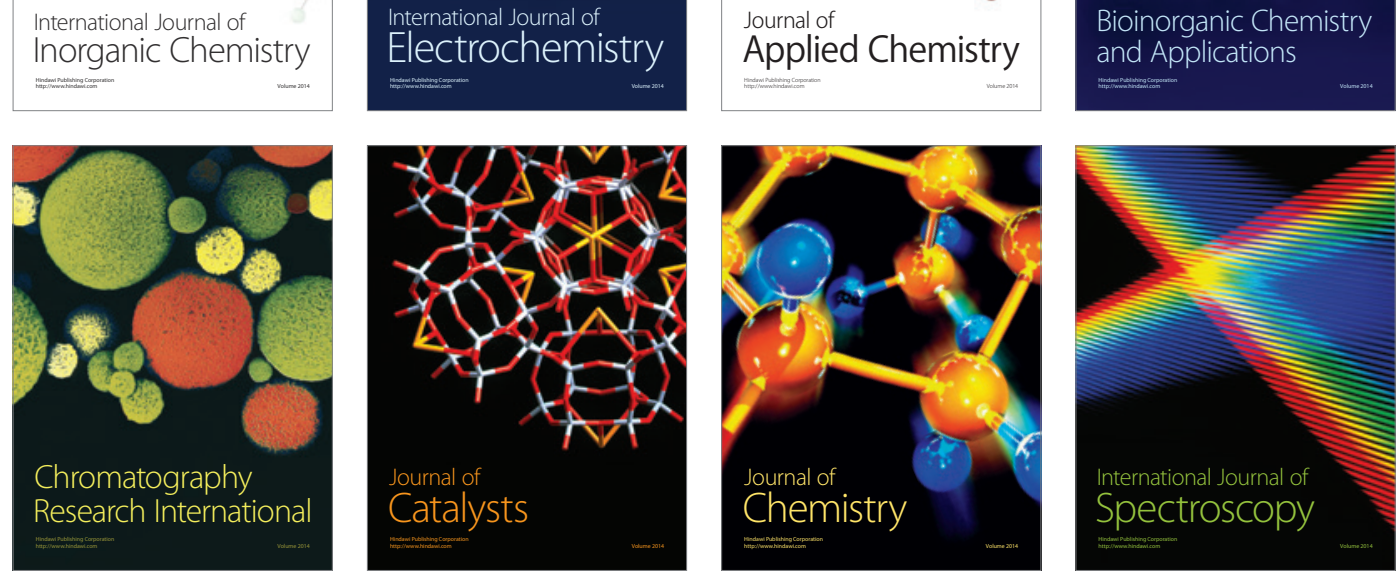